
DOI: https://doi.org/10.29210/2018126 Website: http://icesst.fipunp.ac.id Padang, February $14^{\text {th }}-15^{\text {th }} 2018$

\title{
Analysis of educational values in boikot short stories by Putu Wijaya and the relevants as a learning study level senior high school class XI
}

Bunga Febrimora Hendri

STKIP YDB, Lubuk Alung - Indonesia, (bungafebrimora@rocketmail.com)

\begin{abstract}
This study aims to describe religious values, and moral values in Boikot short story by Putu Wijawa, and the relevance of this study to Indonesian language learning in schools. The research method used in this research is descriptive method. Descriptive method is used to analyze and describe the educational value of Boikot short story by Putu Wijaya. The data source in this research is Boikot short story by Putu Wijaya. Based on the results of data analysis can be concluded that the Boikot short story by Putu Wijaya's work there are religious values, and moral values. This research can be utilized as learning materials of short story of high school grade XI, especially understand extrinsic element.
\end{abstract}

Keywords: educational values, short stories

\section{Introduction}

Literature is one form of art that uses language as the medium. Talking about literature means talking about creative work. As a creative work, literature can tell and describe human life freely.

One form of literature is a short story. Therefore, short stories are expected to generate positive thoughts for the readers. So readers care about issues related to social life and encourage them to behave well. Short stories can be used as material for contemplation to seek experience because the short story contains educational values. The values contained in a story can affect the behavior of the readers.

Short story learning is also related to the curriculum in school. Based on the curriculum 2013 for senior high school class XI, short story text lessons are in the core competence (KI) 3rd that is understanding, applying, analyzing and evaluating factual, conceptual, procedural, technology, art, culture and humanities knowledge with humanity, nationality, and civilization-related causes of phenomena and events, and applying procedural knowledge to specific areas of study in accordance with their talents 
and interests to solve problems. Basic Competence (KD) 3.3 is to analyze short story text, either through oral and written.

The short story is a story that is read once sat, roughly ranging from half to two hours. It is impossible to read a novel (Poe in Nurgiyantoro 2007: 10).

The element of the builder of a short story is the intrinsic element and the extrinsic element. Which include the intrinsic elements are characters, themes and mandates, plot, background, point of view, and style of language. And the extrinsic element, the element that builds short stories from outside the literary works but indirectly affect the literary works. Educational values include one extrinsic element.

Values are about bad things as well as behavioral settings. Certain values are used as the basis for decision making to behave consistently and become a habit in social life (Zuriah, 2011: 19)

According to Notonegoro (in Kaelan, 2004: 89) educational values in literature is divided into four kinds: moral values, truth values, beauty values, and religious values.

One of the interesting short stories to study the values of education is Boikot short story by Putu Wijaya. The short story tells of a group of students (led by a character named Ami) who opposes a citizen keeping a ghost in his home. Residents began to come to see the ghost and secretly asked for help.

According to Ami "it is quite unbelievable that people in tha country of God-based belief is embraced still own bad spirits or ghosts."

Studies of literary works, especially analyzing the value of inquiri have been carried out by other studies. Ni Kadek Parmini completed his research entitled Analysis of Educational Values on Novel Sang Pemimpi Creation Andrea Hirata. Based on the results of the study of researchers on research similar research is not much different. However, there are differences, namely on the object and subject of research.

In this study, the authors analyze the values of education that includes religious values and moral values. This study aims to describe religious values, and moral values in Boikot short story by Putu Wijawa, and the relevance of this study to Indonesian language learning in schools.

\section{Method}

This research type is qualitative research by using descriptive method. According to Semi (1993: 23), research using descriptive method is a research done by not prioritizing on the numbers, but prioritizing the depth of appreciation of the interaction between concepts under consideration empirically.

The data in this study is the educational values contained in Boikot short story by Putu Wijaya. Data source in this study is Boikot short story by Putu Wijaya published newspaper Suara Merdeka, March 6, 2011. Data collection techniques in this study is a literature study techniques, which read and understand Boikot short stories by Putu Wijaya then find the values of education in the short story them. Data analysis is done with the following steps: (1) giving interpretation and doing description part by part found in the research, (2) formulated general conclusion about result of data description, (3) present completed research result in written form. 


\section{Results and Discussion}

Based on the data analysis that has been done, the results obtained that the educational calues contained in the short story Boikot Putu Wijaya is as follows.

\section{Religious Values}

Religious value is the point of view that binds man with the creator god of nature and all that. In this short story contains many religious values of education, as found in the following quotation.

First, "it is quite unbelievable that people in tha country of God-based belief is embraced still own bad spirits or ghosts." Ami believes that God exists, in accordance with the first pancasila "Belief in the One Supreme", meaning every human being must practice the teachings of religion first. In accordance with one of the meanings of this first pancasila that is, believe and taqwa to God Almighty according to their religion and belief each according to humanity base which is fair and civilized.

Second, "don't be late. Because, clearly it will drown the people into a dream." Ami does not want people to sink into a dream world that will ultimately lead people astray (believe in the occult as shamans, etc.).

Third, "Its time for the mystical world, heresy and the like to be brushed away. Indonesia people must live rationally, realistically, and work if they want to move forward." According to Ami the mystical world, heresy and such should be removed, discarded, do not trust. If someone wants to go forward to work hard, do not ask for success to the ghost.

\section{Moral Value}

Moral value are often equated with the value of etnics, which is a value that becomes the size of human worth hanging out in social life. In this short story contains many moral values of education, as contained in the following quotation:

First, "School children also come, want to graduate without having to learn." Without learning, the schoolchildren are convinced that the ghost will pass them.

Second, "There are corruptors who asked the him caught be not petty, it is not giving up, but to continue his carer." The corruptors who came there and asked for help to the ghost wanted his act not to get caught, and he could continue his act (his career).

Third, "Yes, Mr. Amat, I have a note.If summed up, since keeping the ghost, I have dinated al,ost Rp. 50 million to Mr. RW to be utilized for our environment. That's all I get from those who visit want to chat with ghosts. But why am I cursed by an honorable official like Mr. RW?" The ghost owner talks with Mr. RW, he tries to give an explanation for Mr. RW to accept his explanation, and take sides with him. However, it does not mean that by counting the help he has given to the environment, he can justify the wrong thing he did (the ghost owner).

Discussion of this research is described in educational value in short story Boikot by Putu Wijaya. The value of education is a thing that is believed to be true and encourages people to do positive in their own life or in society. According to Notonegoro (in Kaelan, 2004: 89) the value of education in literature is divided into four kinds: moral values, truth values, beauty values, and religious values. The value contained in the short story Boikot by Putu Wijaya there are two, namely religious values and moral values. 
Mangunwijaya (in Lathief, 2008: 175) suggests that all literature is religious. Religious is derived from the Latin relego, intended by reconsidering or concerned about (something). A religious person can be defined as a meaningful human being, who is conscientiously serious, pious, conscientious, and full of spiritual considerations. (Lathief, 2008: 175). The value of religious education in the short story Boikot by Putu Wijaya displayed the author through a character named Ami.

In general morals that is understanding (teachings about) good bad generally accepted about the actions, attitudes, obligations and so forth. Moral in literary works is always in good sense. Thus, if in a work is shown the attitude and behavior of the less praiseworthy characters, it does not mean that the author advises the reader to behave and tame in this way. Models that are less good, which deliberately displayed precisely so as not followed (Nurgiyantoro, 2007: 323). The value of moral education in the short story Boikot by Putu Wijaya works is shown through a character named Ami, and the owner of a ghost.

\section{Conclusions}

Based on the analysis of the results presented, the researcher concludes that the Boikot short story by Putu Wijaya has the value of religious education and moral education value. Therefore, the analysis in this study can be used as knowledge for every person who has read the Boikot short story by Putu Wijaya works and can take the positive values of the short story.

Analysis of this research can be implemented as learning materials short story high school grade XI, Especially on the material analysis of extrinsic element of short stories.

\section{Acknowledgments}

Iwold like to thank my friends and tha chairman on the prodi of my work who has assisted me in completing this research. So i can solve all the obstacles i encountered during my research. I work at STKIP YDB Lubuk Alung who has funded my research.

\section{References}

Kaelan. (2004). Pendidikan Pancasila. Paradigma: Yogyakarta.

Lathief, Supaat I. (2008). Sastra: Eksistensialisme - Mistisisme Religius. Lamongan: Pustaka Ilalang

Nurgiyantoro, Burhan. (2007). Teori Pengkajian Fiksi. Yogyakarta: Gadjah Mada University Press.

Semi, M. Atar. (1993). Metode Penelitian Sastra. Padang: IKIP Padang Press.

Zuriah, Nurul. (2011). Pendidikan Moral dan Budi Pekerti: Dalam Perspektif Perubahan. Jakarta: Bumi Aksara. 